\title{
Exploring the Indonesian Tourism Destination via Indonesia.Travel @indtravel
}

\author{
Arissetyanto Nugroho ${ }^{1}$,Janfry Sihite ${ }^{2}$ \\ ${ }^{12}$ Universitas Mercu Buana, Jakarta, Indonesia \\ Email : ${ }^{1}$ arissoehardjo@mercubuana.ac.id and ${ }^{2}$ janfry.sihite@ mercubuana.ac.id
}

\begin{abstract}
The tourism destination promotion is one of the component to develop the competitiveness index for travel and tourism. An exploratory @indtravel, indonesia tourism destination promotion twitter channel conducted to elaborate the promotion strategy. A content analysis conducted for 1196 tweet from @indtravel that promote Indonesian tourism. The findings show that most of the destination promoted by images compare with videos. Most of the scene are the sea, sand and sun. Further recomendation delivered to promote the Indonesian cultural resources@indtravel, therefore the potential tourist could explore Indonesia before finally decide to visit Indonesia.
\end{abstract}

Keywords-Tourism; Promotion; Twitter

\section{INTRODUCTION}

The contribution of tourism for Indonesian revenue continued to rise, in 2015 the tourism revenue still ranked fourth below the oil \& gas, coal and palm oil. While in 2016 is already ranked second after palm oil. In the year 2019 will most likely the tourism revenue will be the largest contributor since oil \& gas, coal and palm oil production continued to decline, while tourism continues to grow.

The number of foreign tourists visit to Indonesia for the period January to November 2017 shows a good trend that reached 12.68 million visits or $21.84 \%$ increase compared with the number of foreign tourist visits in the same period a year before with the number of 10.41 million visits (Biro Pusat Statistik, 2017). The development of this tourism sector pushes the Government to develop the Indonesia tourism as the core business (Kementrian Pariwisata, 2016) and further improve the competitiveness of the Indonesia tourism.

Social networking applications such as facebook and twitter have a significant impact for tourism. Facebook is becoming a fast growing application for tourists because there is interaction between the travellers with tourists as well as prospective tourists in the facebook application (Di Pietro \& Pantano, 2013). Social networking applications such as twitter gives more benefits compared to the echannel or channels of communication such as internet websites. If in the website, visitors get information about tour options, social networking gives the same information, with additional transparency, response from users over a wide range of information submitted in the social network account.

Social network mediate the tourism development in Indonesia, targeting diverse market, covering all of the people in various parts of the world. These benefit leverages the social networking applications. Social network also increase the impact of the collaboration among tourism stakeholder on promoting the tourism industry by integrating various services together with travel operators, managers of tourist attractions and a wide range of services and products other tourism (solution channel) (Nugroho \& Sihite, 2015) (Sihite \& Nugroho, 2017) (Nugroho, 2017).

The remainder of the paper is organized as follows. In Section 2, we introduce the literature and background references for the ideas. We describe the methodology for the exploratory in section 3 . Then the results and discussion in section 4. Finally, we describe the future work in Section 5. 


\section{LITERATURE REVIEW}

The Travel Tourism Competitiveness Index 2017 report the World Tourism competitiveness report such as the infrastructure, the priority of the Government in tourism, natural resources, and other components weighted than produce a total score for the tourist destinations competitiveness index (World Economic Forum, 2017). The interesting thing is the ranking of the five best world tourist destinations, which are Spain (1), France (2), Germany (3), Japan (4) and (5) the United Kingdom has a consistent superior values for the cultural resources and business travel component compare with the other component.

The definition of cultural resources and business travel component is "... the availability of cultural resources is intended in a broad sense including archaeological sites, entertainment facilities and conferences. To a large extents this pillar captures how cultural resources are promoted rather than the actual existing cultural heritage of a country. " This component reflect how the promotion of cultural tourism destinations than just the availability of cultural relics. A superior rating for cultural resources and business travel component shows that cultural promotion is an important factor for foreign tourists, along with the other components such as the natural landscape, transportation and infrastructure (World Economic Forum, 2017).

The tourism destination promotion conducted by National Regional Tourism, Regional Tourism Organization and also all stakeholder related to tourism. The national tourism organization promote the tourism destination through planned activities such as posting destination tweet, images, photos via the social network application. The social network application consider the most effective since it could reach varieties of targeted market and efficient since it could reach many audience with low cost.

The tourism promotion strategy considered as the orchestrated promotion activities conducted that could be measured by the travel and tourism competitiveness index. This index consist of many component and weighted for the importance to promote the tourism. The index measured the national tourism promotion competitiveness, therefore the index ranked countries regards to the promotion performance.

\section{METHODS}

\section{A. Data}

This study is an exploratory research in social network account @indtravel. The interval of data in the period January to December 2016 chosen because within this period @indtravel promote Indonesian tourism destination. This period of promotion influence the Indonesian tourism performance in 2017 when the tourist arrival reach 21,84\% improvement.

\section{B. Method}

The method conducted is content analysis for the element projected in the destination images within the tweet. Content analysis is the preliminary phase to categorize the themes within the unit analysis. A content analysis for the images within the tweet conducted by categorizing cognitive element within the image.

The topics explored by collecting the tweet, and categorizing relevant topics regards to the images, whether the tweet photo or video, whether the images of the tweet a natural resources, cultural resources, whether it is the sky, the sea, the sand, beach, temple, monuments. Each category will further totaled therefore we got the proportion for each category (Nugroho, Sihite, 2015a; Nugroho, Sihite, 2015b, Nugroho, Sihite, 2015c)

\section{A. Result}

\section{IV.RESULT AND DISCUSSION}

The exploratory on Indonesia.Travel twitter @indtravel which is a twitter of Indonesia Tourism Ministry expose the tourist destination promotion activities in Indonesia. Within the period of January to December 2016 there are total of 1331 tweet, further categorization conducted, therefore there are 
1196 tweets categorized as tweet that promote Indonesia tourist destinations. Total 99\% (1185 tweets) are photos and 0.9\% (11 tweets) are videos. 1196 tweet categorized and there are 1131 tweets images of the natural landscape of Indonesia. The majority of images are the sky, the sea, mountains, beaches, forests, coral, and other images. The number of tweets that display the Indonesia culture are temple (38 tweets), and ancient buildings (33 tweets) which still relatively little compared with the natural landscape.

In addition there are 282 images of art and culture shown @indtravel in the period 2016. The majority images are a cultural clothing (65 tweets), local food (47 tweets), monuments (39 tweets), custom homes (39 tweets), as well as other cultural and artistic display.

\section{B. Discussion}

Efforts to improve the Indonesia tourist destination competitiveness should start with the cultural promotion. Indonesia is currently ranked 23rd for the cultural resources and business travel component, compared with the other components then this component is the most potential components to be improved. The promotion should synergy with the other collaboration activities in social media who have the same objective to improve tourism sector in Indonesia.

Statistical data the company's twitter followers in Indonesia shows that 2 of the 5 companies with the most followers are companies that promote tourist destinations. Socialbakers.com displays the first rank with 3.89 million followers, namely Air Asia (@AirAsia_Indo) and ranked fourth with 3.29 million followers is Garuda Indonesia (@IndonesiaGaruda). The two companies are an airline companies that that showcases its proposition, namely travel tickets by displaying tourist destinations Indonesia (Janfry Sihite, Harun, \& Nugroho, 2015) (Socialbakers, 2015).

Indonesia travel (@indtravel) has 1.34 million followers, the number of people who follow the airline's twitter@AirAsia_Indo and @IndonesiaGaruda as well as @indtravel strengthen the role of social media for the promotion of tourist destinations Indonesia. Distribution the distribution of tourist destinations are shown in the @indtravel also include tourist destinations in Java (234 twit), Sumatra (109 twit), Bali (78 twit), NTT (twit 73), WNT (54 twit), Guinea (45 twit), Sulawesi (36 twit), Kalimantan (27 twit) and 6 (the Bangka Belitung twit). Variations in the distribution of wealth shows variations of the tourist destinations on the island of Java and Sumatra are still most widely promoted, and the promotion of tourist destinations from other geographic distribution can still be optimized.

\section{CONCLUSION}

The times also has brought us into the era of the development of tourist destinations with the image of organic imagery versus induced. Typology of organic imagery and induced image is the typology construction of the image of tourist destinations delivered by Gunn in 1972. At the time, promotional activities through advertising different tourist destinations with a show on television featuring tourist destinations.

Events in this television is not part of the promotion, ads in magazines featuring tourist destinations is also considered not related to marketing of tourist destinations. The era of the it channel marketing communications still are limited, such as television, radio, magazines, newspapers and so the concept of organic imagery as a tourist the impression towards destinations without visiting destinations are still relevant. The impression was obtained from indirect sources not related to marketing activities. This is a difficult dikontekstualisasikan into the current era as we are exposed to a variety of information that the spectrum of activities vary from soft to hard selling selling promotional activities tourist destinations.

The challenge facing today is how to manage the promotion by image induced, IE the image obtained from the results of the promotional efforts of various stakeholders such as marketers, corporate travel tourism destinations as well as hotels in destinations as well as marketing that was done by a country or a region to be able to build the image of the desired destinations. This challenge is more difficult because of the wide variety of promotional activities to these tourist destinations will be exposed to millions of prospective tourists through the gadget they have and they will also expose the user generated content that conveys the image of organic as a part of self expression when they travel to tourist destinations. 
Eventually the process to build the image of tourist destinations Indonesia needs a marketing communication channel dedicated to optimize promotion of culture of Indonesia which will increase the tourist attraction in Indonesia and variations in tourist destinations in Indonesia. Promotion by the induced image into this marketing communication channels will make it easier for would-be travelers to explore Indonesia before finally settling for tourism in Indonesia.

\section{REFERENCES}

Barreda, A., \& Bilgihan, A. (2013). An analysis of user-generated content for hotel experiences. Journal of Hospitality and Tourism Technology, 4(3), 263-280. doi:10.1108/jhtt-01-20130001

Biro Pusat Statistik, B. (2017). Jumlah Wisatawan Asing Tahun 1974 - 2015, Devisa Wisman 19982015 dan Tingkat Penghunian Kamar (TPK) Hotel Bintang dan Non Bintang Tahun 1985 . 2015. Retrieved from

Di Pietro, L., \& Pantano, E. (2013). Social network influences on young tourists: An exploratory analysis of determinants of the purchasing intention. Journal of Direct, Data and Digital Marketing Practice, 15(1), 4-19. doi:http://dx.doi.org/10.1057/dddmp.2013.33

Kementrian Pariwisata, K. (2016). Rakornas Ke-3 Pariwisata "Go Digital Be The Best". Retrieved from

Mo Kwon, J., Bae, J. i., \& Blum, S. C. (2013). Mobile applications in the hospitality industry. Journal of Hospitality and Tourism Technology, 4(1), 81-92. doi:10.1108/17579881311302365

Nugroho, A. (2017). ASEAN Tourism Marketing Communication Attribute: An Exploratory Research at Goaseantv. European Research Studies Journal, XX(3).

Nugroho, A., \& Sihite, J. (2015a). Does The Social Network Relate With The Entrepreneurship? An Empirical Content Analysis. Manajemen, XIX(2).

Nugroho, A., \& Sihite, J. (2015b). Is It A Relational Marketing Strategy? Cluster Analysis @Universitasmercubuanajakarta Facebook Post and Comment. Manajemen MIX, V(2).

Nugroho, A., \& Sihite, J. (2015c). Is It Traditional or Contemporary Marketing Strategy? A Textual Cluster Analysis @MercuBuana_Reg. Mediterranean Journal of Social Sciences, VI(5).

Nugroho, A., \& Sihite, J. (2015). Tweeting And Retweeting Tourism And Airline Service Attributes. Thomson Reuter Indexed Proceeding. International Geographical Union \& Lombok International Conference. University Mataram.

Nugroho, A., \& Sihite, J. (2016). Exploratory Factor Analysis Syariahmandiri and Bankmandiri Service Attributes 2015. . The Social Sciences, 11, 4896-4901.

Sihite, J., Harun, T. W., \& Nugroho, A. (2015). The Low Cost Airline Consumer Price Sensitivity. An Investigation on The Mediating Role of Promotion and Trust in Brand. International Research Journal of Business Studies, VII(3).

Sihite, J., \& Nugroho, A. (2017). Brand Extension In The Marketspace Journal of Economic \& Management Perspectives, 11(3).

Socialbakers, S. (2015). Social Marketing Report: Indonesia Regional. Retrieved from

World Economic Forum, W. (2017). The Travel \& Tourism Competitiveness Report 2017. Retrieved from 